\title{
Determinant Analysis of Salesperson's Performance at PT. Prima Zirang Utama Semarang
}

\author{
Widiartanto ${ }^{1, *}$, Wahyu Hidayat ${ }^{2}$ \\ ${ }^{\mathbf{1}}$ Departemen of Business Administration, Diponegoro University, Semarang, Indonesia \\ ${ }^{2}$ Departemen of Business Administration, Diponegoro University, Semarang, Indonesia \\ *Email: widi.fisip@gmail.com
}

\begin{abstract}
The purpose of this research is to test empirically the effect of salesperson behavior, sales activity planning, and performance orientation on salesperson performance at PT. Prima Zirang Utama Semarang. The research method used is the survey method, namely research that takes a sample from a population and uses a questionnaire as the main data collection tool. The type of research used is explanatory research. The samples studied were all salespeople at PT. Prima Zirang Utama Semarang, totaling 36 people. The result of this research is that there is a positive and significant influence between the salesperson's behavior, sales activity planning, and performance orientation on the salesperson's performance. This can be seen from the significant value in the ANOVA recapitulation of 0.026 indicating a value smaller than 0.05 . This means that the regression model is feasible to predict the effect of salesperson behavior variables, sales activity planning, and performance orientation on salesperson performance variables.
\end{abstract}

Keywords: PT. Prima Zirang Utama Semarang; salesperson behavior; sales activity planning; performance orientation; salesperson performance

\section{Introduction}

Selling got serious attention in the $19^{\text {th }}$ century when the first person who pioneered the science of selling was John Wanamaker (1865) in the United States. He is known as the "service principle" which adheres to the idea of providing the best service, then eventually the market will grow in front of your house. In 1884, Arthur E. Sheldon developed the service principle into personal selling and then officially became the science of salesmanship. For this reason, Sheldon is considered a pioneer in the science of selling (Kotler and Keller, 2016).

Robert Louis Stevenson observes that "everyone lives by selling something." American companies spend more than \$ 140 billion per year on personal sales, more than they spend on other promotional methods. More than 11 million Americans work in sales and associates (Anderson, 1995 and Dalrymple, 1994). One company has a different goal than another for their sales force. IBM sales representatives are responsible for selling, installing, and upgrading customers' computer equipment, as well as helping customers troubleshoot problems. AT\&T sales representatives are responsible for developing, selling, and protecting their accounts (Kotler and Keller, 2016).
Nobody disputes the importance of a sales force in the marketing mix, especially for high-value products. However, companies are very sensitive to high and increasing costs (salaries, commissions, bonuses, travel expenses, and allowances) for maintaining a sales force. So companies need to carefully consider when and how to use the sales force. Unsurprisingly, the company is trying to shift to postal and telephone sales to lower the cost of field sales. And they try to increase the productivity of the remaining sales force through better selection, training, motivation, and compensation (Sager, 1994).

In many companies, the sales force is the key to implementing a marketing strategy (Lilien, Rangaswamy, and Matanovich, 1998). Salesforce performance is measured by total sales volume (Dubinsky and Barry, 1982; Jackson, Keith, and Sclacter, 1983; Morrs, Davis, Allen and Avilla, 2013). Thus, if the sales force's performance is good, the amount of sales volume achieved will be large. This shows that the sales force's performance will have a positive effect on sales performance.

According to Kohli, Shervanni, and Challagalla (1998), there are still few studies that highlight the factors that lead to learning orientation and performance in salespeople. Based on their research results, especially those concerning performance orientation, the 
results indicate that performance orientation has a positive effect on sales force performance. This is still in line with the findings of Sujan, Weitz, and Kumar (1994).

Sales personnel activity coupled with behavioral performance (eg building customer relationships, retaining existing customers) should enhance yield performance. Results are obtained as a consequence of sales personnel effort and skills, and there is conceptual and empirical support to suggest that higher sales personnel behavioral performance leads to higher yield performance (Anderson and Oliver, 1987; Babakus, et.al, 1996; Cravens, et.al., 1993).

The research results of Walker, Churchill, and Ford (1997), explain that the behavior of salespeople is the factor that provides the greatest contribution to improving salesperson performance compared to organizational factors and the external environment. However, Barker's (1999) research provides empirical evidence that there is no statistically significant difference between high and low salesperson performance due to the salesperson's ability. Thus, it can be concluded that other factors influence the level of salesperson's performance.

Likewise, at PT. Prima Zirang Utama, which is located at $\mathrm{Jl}$. A. Yani No. 170 Semarang, which is engaged in the business of selling Honda brand new motor vehicles and using salesforce as the spearhead of its marketing. As of May 2020, the company has a sales force of 36 people with qualifications of S0, S1, S2, and S3, with the understanding that $\mathrm{S} 0$ is a salesperson who is undergoing a training period while $\mathrm{S} 1, \mathrm{~S} 2$, and $\mathrm{S} 3$ indicate a working period of 1 year, 2 years, and 3 years or more.

The company has also started spreading its subsidiaries to several big cities aimed at expanding its business to provide ease of service and trying to be closer to customers, as well as trying to provide good and professional service satisfaction in the automotive sector according to the needs desired by customers. To support sales activities to achieve the desired target, the company provides a showroom for motorized vehicles specifically for the Honda brand.
Sales of these vehicles to customers are also carried out by setting sales targets through the sales force. The company applies a quarterly target which is measured by the number of motorized vehicles that salespeople must sell. The sales targets per sales qualification are as follows: a) Qualification S0 with a target of 15 units per 3 months; b) S1 qualification with a target of 24 units per 3 months; c) S2 qualification with a target of 30 units per 3 months; and d) S3 qualification with a target of 39 units per 3 months.

The developments over the last three years about the target and realization of motor vehicle sales are as shown in Table 1.1 below.

Table 1. Development of Target and Realization of Motor Vehicle Sales 2017 s/d 2019 (in units)

\begin{tabular}{cccc}
\hline Year & Target & Realization & $\%$ \\
\hline 2017 & 840 & 835 & 99,4 \\
\hline 2018 & 1080 & 1076 & 99,6 \\
\hline 2019 & 1470 & 1468 & 99,86 \\
\hline
\end{tabular}

Source: Company Data (2019)

Based on the table above, it can be seen that even though the sales realization tends to increase each year, during the last 3 years the sales target has never been achieved $100 \%$. So that the problem that arises in this research is that the planned sales target has not been achieved. So the research question that can be formulated is whether there is an influence between salesperson's behavior, sales activity planning, and performance orientation on salesperson performance?

\section{Literature Review}

Various factors can affect a salesperson's performance. As research started by Barker (1999) provides empirical evidence that sales planning and adjustments will affect salesperson performance levels. In his research, Barker stated that planning sales activities are an activity that needs to be done because it can improve sales force performance. Furthermore, it is said that companies that have high performance are found to have salespeople who plan each sales visit, plan sales strategies for each customer, and plan their daily activities. Likewise, Piercy, et.al (1997) emphasized that salesperson's performance can be achieved if sales planning is carried out. In that study. 
Piercy, et.al saw that salespeople have high sales performance when supervisors can plan sales strategies for their customers and plan sales territories and customers, plan sales visits, and daily activities for salespeople.

Another study by Sujan, Weitz, and Kumar (1994) focused on two different salesperson orientations, namely learning and performance. Salespeople with a learning orientation have a strong desire to continuously improve and master their skills and selling ability and see situations as opportunities to improve their competence (Dweek and Leggett, 1988). In contrast, performance-oriented salespeople focus on a good performance because they see good performance as a means of gaining appreciation from others (eg, supervisors). Performance-oriented people pay attention to the presumption of being able and show evidence of their ability and success (Ames and Archer, 1998). According to Dweek and Legget (1998), people who have a learning orientation do not bother with making mistakes and keep trying if they fail. Conversely, performance-oriented people will stick with it if they feel they are highly skilled in that area. From an organizational viewpoint, performance orientation leads to short-term results, for example, increased sales, whereas learning orientation increases skills and abilities for better long-term performance (Kohli, Shervanni and Challagalla, 1998).

\section{The Effect of Salesperson's Behavior on Salesperson's Performance}

Walker, et.al (1979 in Plank and Reid, 1994) say that salesperson performance is a consequence of organizational personnel and environmental factors so that to improve salesperson performance, companies must pay attention to these three aspects. In line with this statement, this research uses sales planning and adjustment as a proxy and organizational and environmental factors. Meanwhile, personnel factors are proxied by salesperson behavior and performance orientation.

Behrman and Perreault (1982) and Weitz (1981) state that salesperson behavior has a positive effect on salesperson performance. In this case, salesperson's behavior is an unobserved variable explained by the dimensions of learning orientation (Kohli, Shervani and Challagalla, 1998), interpersonal communication (Boorom, et.al, 1998; Renttz, et.al, 2002; Kurniawati, 2003), and hard-smart work (Sujan, Weitz and Kumar, 1994); Sitompul, 2004). Salesperson's behavior is the effort made by salespeople concerning the job duties they carry out. Meanwhile, Babakus, et.al (1996) stated that salesperson's behavior is seen from how well each salesperson carries out his activities when carrying out his job duties. Thus, the salesperson's behavior can be evaluated because of its contribution to the achievement of company goals.

\section{The Effect of Sales Activity Planning on Salesperson's Performance}

Sales planning and adjustments are expected to affect salesperson performance. This is by the research suggestions of Baldauf, Cravens, and Pircy (2001) to include these factors in future research models. Previously, Balker's (1999) research provided empirical evidence that sales planning and adjustments would affect the salesperson's performance. In his research, Balker stated that planning sales activities are an activity that needs to be done because it can improve salesperson performance. Furthermore, it is said that companies that have high performance are found to have salespeople who plan each sales visit, plan sales strategies for each customer, and plan their daily activities. Likewise, Piercy, et.al (1997) emphasized that salesperson's performance can be achieved if sales planning is carried out. In this study, Piercy, et.al saw that salespeople have high sales performance when supervisors can plan sales strategies for their customers and plan sales territories and customers, plan sales visits, and daily activities for salespeople.

\section{The Effect of Performance Orientation on Salesperson's Performance}

According to Kohli, Shervanni, and Challagalla (1998) in their research that highlights the factors that lead to learning orientation and performance in salespeople are still few. Based on their research results, especially those concerning performance orientation, the results indicate that performance orientation has a positive effect 
on sales force performance. This is still in line with the findings of Sujan, Weitz, and Kumar (1994).

Performance-oriented salespeople focus on a good performance as a way to get rewards and/or rewards from other salespeople. They compare their performance to each other's expectations of supervision and the performance of their coworkers. Their desire for recognition from others allegedly drives them to put more effort into their jobs which in turn leads to higher performance. Empirical evidence reported by Sujan, Weitz, and Kumar (1994) supports this opinion. Furthermore, a performance-oriented salesperson will likely select his tasks according to his goals, thereby maximizing their success rate.

The hypothesis formulated in this study are as follows:

a. It is assumed that there is a positive and significant influence between the salesperson's behavior on the salesperson's performance.

b. It is suspected that there is a positive and significant influence between planning sales activities on salesperson performance.

c. It is assumed that there is a positive and significant influence between performance orientation on salesperson performance.

d. It is suspected that there is a positive and significant influence between sales behavior, sales activity planning, and performance orientation on salesperson performance.

\section{Method}

The research method used is the survey method, namely research that takes a sample from a population and uses a questionnaire as the main data collection tool. The research used is explanatory. The research location is at PT. Prima Zirang Utama Semarang. Meanwhile, the target in this study focuses on

Table 2. Validity and Reliability Test

\begin{tabular}{|c|c|c|c|c|c|}
\hline Number & Item & r test & $\approx$ & r table & Conclusion \\
\hline \multicolumn{6}{|c|}{ Salesperson's Behavior } \\
\hline 1 & Knowledge of products supports work & 0.813 & $>$ & 0.396 & Valid \\
\hline 2 & $\begin{array}{l}\text { Knowledge about marketing supports } \\
\text { the job }\end{array}$ & 0.804 & $>$ & 0.447 & Valid \\
\hline 3 & Use of overtime & 0.802 & $>$ & 0.473 & Valid \\
\hline 4 & Knowledge of company profile & 0.814 & $>$ & 0.352 & Valid \\
\hline 5 & Knowledge about product knowledge & 0.802 & $>$ & 0.475 & Valid \\
\hline 6 & Knowledge of consumers/customers & 0.805 & $>$ & 0.434 & Valid \\
\hline 7 & $\begin{array}{l}\text { Knowledge of the company's marketing } \\
\text { strategy }\end{array}$ & 0.808 & $>$ & 0.393 & Valid \\
\hline \multicolumn{6}{|c|}{ Sales Activity Planning } \\
\hline 1 & Daily activity planning & 0.791 & $>$ & 0.625 & Valid \\
\hline 2 & Sales strategy planning & 0.804 & $>$ & 0.450 & Valid \\
\hline 3 & Sales visit planning & 0.797 & $>$ & 0.532 & Valid \\
\hline \multicolumn{6}{|c|}{ Performance Orientation } \\
\hline 1 & Get rewards from companies & 0.824 & $>$ & 0.356 & Valid \\
\hline 2 & Trying to exceed sales targets & 0.807 & $>$ & 0.508 & Valid \\
\hline 3 & Trying to get a profit margin & 0.805 & $>$ & 0.442 & Valid \\
\hline \multicolumn{6}{|c|}{ Salesperson's Performance } \\
\hline 1 & Increased supply intensity & 0.802 & $>$ & 0.473 & Valid \\
\hline 2 & An increase in the unit of product sold & 0.807 & $>$ & 0.392 & Valid \\
\hline 3 & Increase in new customers & 0.801 & $>$ & 0.515 & Valid \\
\hline \multicolumn{6}{|c|}{ Reliability Test } \\
\hline Cronba & Alpha & \multicolumn{3}{|c|}{ N of Items } & Conclusion \\
\hline & 0.815 & \multicolumn{3}{|c|}{16} & Reliable \\
\hline
\end{tabular}

Source: SPSS Output 
the salesforce. The population in this study was the salesforce at PT. Prima Zirang Utama Semarang, amounting to 36 people. The census was used as a sampling technique in this study, namely by examining all populations as the research sample.

\section{Result}

In the data processing, validity and reliability tests were used. These two tests were carried out because the instruments in the questionnaire had to be valid/valid and reliable/reliable so that they would also produce valid and reliable research. The following table shows the validity and reliability of tests.

The majority of respondents (91.7\%) were male and only a small proportion $(8.3 \%)$ were female. The majority of respondents $(52.8 \%)$ have no family dependents. The majority of respondents $(55.6 \%)$ have worked in companies for between 1 and 2 years. The majority of respondents had an income/month of between Rp. 3,000,000 to Rp. 3,500,000.

Table 3 is a recapitulation of the model and regression equation using simple linear regression analysis and multiple linear regression to test the influence between variables partially or simultaneously.

Based on Table 3, it can be seen that: salesperson's behavior has a positive and significant effect on the salesperson's performance at PT. Prima Zirang Utama Semarang. This is evidenced by the regression coefficient value of 0.231 . The correlation test

result is 0.405 , which means that the relationship between the two is moderate. The coefficient of determination is $16.4 \%$, which means that the contribution of the influence of the salesperson's behavior in explaining the salesperson's performance at PT. Prima Zirang Utama Semarang amounted to $16.4 \%$. The significance value (in the sig column in Table 2) of the salesperson's behavior variable is 0.014 , indicating a value smaller than 0.05 . This means that the regression model is feasible to predict the effect of salesperson behavior variables on salesperson performance variables or in other words, there is an influence between salesperson behavior variables on salesperson performance variables ( $\mathrm{H} 1$ is accepted and $\mathrm{H} 0$ is rejected).

On the influence of planning sales activities on salesperson performance, it is known that there is a positive and significant influence. This is evidenced by the regression coefficient value of 0.364 . The result of the correlation test is 0.424 , which means that the relationship between the two is moderate. The coefficient of determination is $18 \%$, which means that the contribution of the sales activity planning influence in explaining the salesperson's performance at PT. Prima Zirang Utama Semarang amounted to $18 \%$. The significance value (in the sig column in Table 2) of the sales activity planning variable is 0.010 , which indicates a value smaller than 0.05 . This means that the regression model is feasible to predict the effect of the sales activity planning variable on the salesperson's performance variable or in other words, there is an influence between the sales activity planning variable on the salesperson's performance variable ( $\mathrm{H} 1$ is accepted and $\mathrm{H} 0$ is rejected).

Still based on Table 3 above, it can be seen that the performance orientation has a

Table 3. Recapitulation of Influence Between Variables

\begin{tabular}{lcccccccc}
\hline \multicolumn{1}{c}{ Relation } & $\mathbf{R}$ & $\begin{array}{c}\mathbf{R} \\
\text { Square }\end{array}$ & $\begin{array}{c}\text { Adj. } \mathbf{R} \\
\text { Square }\end{array}$ & $\begin{array}{c}\text { Const } \\
\cdot\end{array}$ & B & Beta & t & Sig. \\
\hline PTP-KTP & 0.405 & 0.164 & 0.139 & 5.060 & 0.231 & 0.405 & 2.583 & 0.014 \\
\hline & & & & & & & & \\
\hline PKP-KTP & 0.424 & 0.180 & 0.156 & 6.803 & 0.364 & 0.424 & 2.733 & 0.10 \\
\hline & & & & & & & & \\
\hline OK-KTP & 0.315 & 0.099 & 0.073 & 6.317 & 0.375 & 0.315 & 1.937 & 0.041 \\
\hline & & & & & & & & \\
\hline PTP, PKP \& OK- & 0.498 & 0.248 & 0.177 & 3.168 & 0.111 & 0.194 & 1.020 & 0.032 \\
KTP & & & & & 0.233 & 0.271 & 1.468 & 0.015 \\
& & & & & 0.204 & 0.171 & 1.037 & 0.031 \\
\hline
\end{tabular}

Source: SPSS Print Out 
positive and significant effect on the salesperson's performance at PT. Prima Zirang Utama Semarang. This is evidenced by the regression coefficient value of 0.375 . The result of the correlation test of 0.315 means that the relationship between the two is weak. The coefficient of determination is $9.9 \%$, which means that the contribution of the influence of performance orientation in explaining the performance of salespeople at PT. Prima Zirang Utama Semarang amounted to $9.9 \%$. The significance value (in the sig column in Table 2) of the performance orientation variable is 0.041 which indicates a value smaller than 0.05 . This means that the regression model is feasible to predict the effect of the performance orientation variable on the salesperson's performance variable or in other words, there is an influence between the performance orientation variable on the
The coefficient of determination is $24.8 \%$, which means that the contribution of the influence of salesperson's behavior, sales activity planning, and performance orientation in explaining the salesperson's performance at PT. Prima Zirang Utama Semarang amounted to $24.8 \%$. The significance value of the ANOVA recapitulation of 0.026 indicates a value smaller than 0.05 . This means that the regression model is feasible to predict the influence of salesperson behavior variables, sales activity planning, and performance orientation on salesperson performance variables, or in other words, there is an influence between salesperson behavior variables, sales activity planning, and performance orientation on personnel performance variables. seller (H1 accepted and Ho rejected).

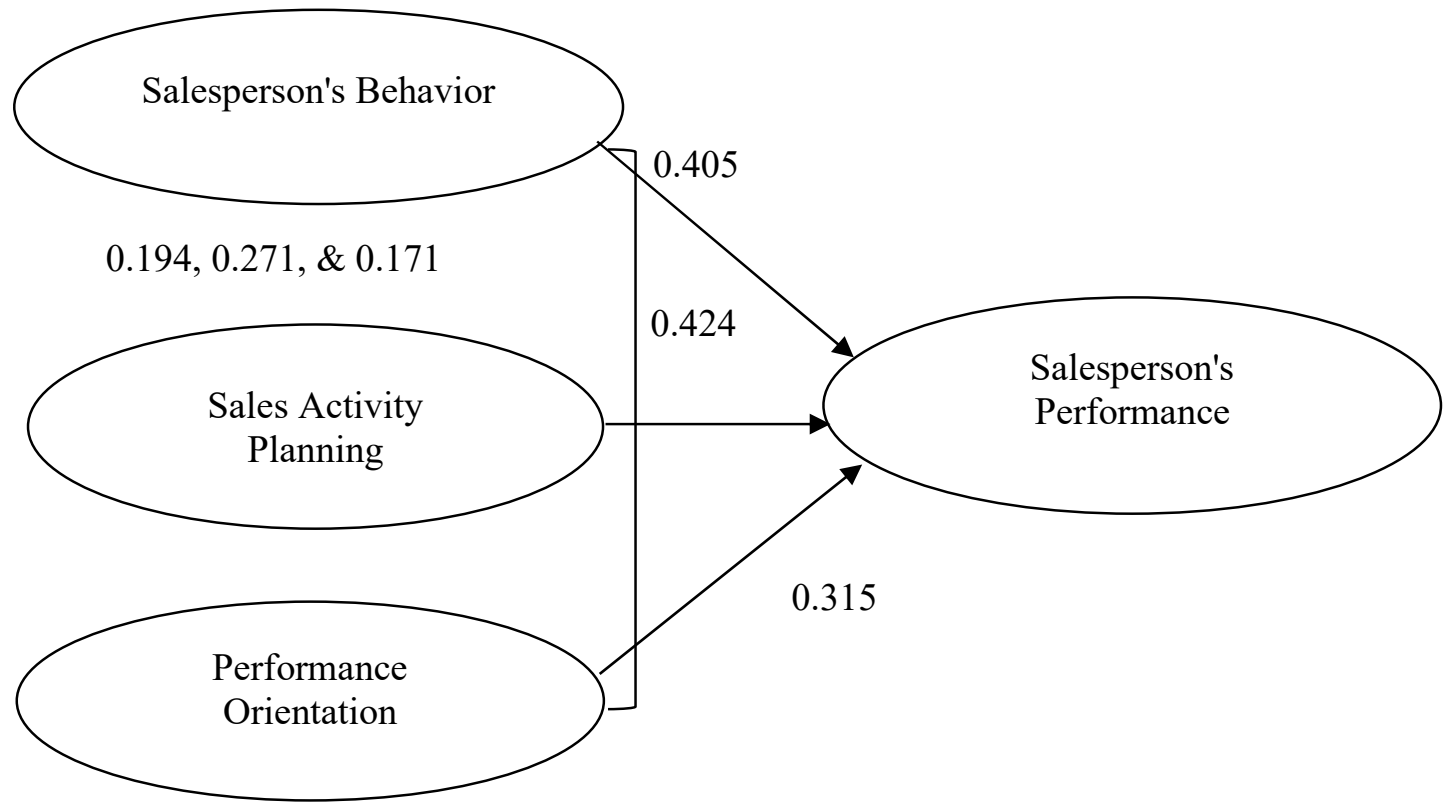

Figure 1. Multiple Regression Model

Source: Primary Data Processed, 2019

salesperson's performance variable (H1 is accepted and $\mathrm{H} 0$ is rejected).

While the influence of salesperson behavior, sales activity planning, and performance orientation on salesperson performance, it is known that there is a positive and significant influence. This is evidenced by the regression coefficient value of $0.111 ; 0.233$; and 0.204 . The result of the correlation test of 0.498 means that the relationship between the three independent variables on the dependent variable is weak.

\section{Discussion}

The assessment of the research variables used the level of interval measurement so that the variables under study could be categorized according to the data obtained. The majority of respondents have salesperson behavior in the very good category ( $88.9 \%$ ) which can be measured from the success in understanding the knowledge of the products being sold, the use of overtime to 
achieve sales targets. However, there are still $(11.1 \%)$ who have salesperson behavior in a good category related to a lack of knowledge about the company profile and marketing strategies.

The majority of respondents had a sales activity plan in the very good category (94.4\%) and the remaining $2.8 \%$ each had a sales activity plan in the category of good enough and good. Daily activity planning, visit planning and sales strategies carried out by respondents are very supportive of the respondent's success in achieving sales targets.

The majority of respondents have a performance orientation in the very good category $(97.2 \%)$ and the rest $(2.8 \%)$ have a performance orientation in the good category. The orientation of the respondent's performance is to get a reward by exceeding the sales target and always getting a profit margin.

The majority of respondents have salesperson performance in the very good category $(97.2 \%)$ and the rest $(2.8 \%)$ have salesperson performance in the good category. Salesperson performance is measured by the success in increasing product sales and increasing customers, especially from purchases in offices or agencies.

The results of this study support several previous studies, including research by Lilien, Rangaswamy, and Matanovich (1998); Dubinsky and Barry (1982, Jackson, Keith, and Sclacter (1983), as well as Morrs, Davis, Avilla, and Chapman (1991), wherein many companies, the sales force is the key to implementing a marketing strategy. sales are high, so the number of sales volume achieved will be a lot. This shows that the performance of the sales force will have a positive effect on sales performance. Then it is also in line with the results of research by Behrman and Perreault (1982) and Weitz (1981) which states that salesperson's behavior has a positive effect on salesperson's performance. In this case, salesperson's behavior is an unobserved variable which is explained by the dimensions of learning orientation (Kohli, Shervani and Challagalla, 1998), interpersonal communication (Boorom, et.al, 1998; Renttz, et.al, 2002; Kurniawati, 2003) and hard-smart work (Sujan, Weitz and Kumar, 1994); Sitompul, 2004). Salesperson's behavior is the effort made by salespeople concerning the job duties they carry out. On the other hand, the results of this study support the research of Walker, Churchill, and Ford (1997) which explains that salesperson's behavior is the factor that makes the biggest contribution in improving salesperson performance compared to organizational factors and the external environment, also following the results of research by Anderson and Oliver (1987); Babakus, et.al (1996); Cravens and Morgan (1999), which suggests that sales personnel activities coupled with behavioral performance (eg building customer relationships, retaining existing customers) should improve sales performance.

Sales activity planning affects salesperson performance. This is consistent with the research suggestions of Baldauf, Cravens, and Pircy (2001) to incorporate these factors into future research models. Previously, Balker's (1999) research provided empirical evidence that sales planning and adjustment would affect the salesperson's performance. Likewise, Piercy, et.al (1997) emphasized that salesperson's performance can be achieved if sales planning is carried out. In this study, Piercy, et.al saw that salespeople have high sales performance when supervisors can plan sales strategies for their customers and plan sales territories and customers, plan sales visits, and daily activities for salespeople. 
Performance orientation has a positive effect on sales force performance. This is in line with the research results of Sujan, Weitz, and Kumar (1994). Performance-oriented salespeople focus on a good performance as a way to get rewards and/or rewards from other salespeople. They compare their performance to each other's expectations of supervision and the performance of their coworkers. Their desire for recognition from others allegedly drives them to put more effort into their jobs which in turn leads to higher performance. Empirical evidence reported by Sujan, Weitz, and Kumar (1994) supports this opinion. Furthermore, a performanceoriented salesperson will likely select his tasks according to his goals, thereby maximizing their success rate.

\section{Conclusion}

This study concludes as follows: 1) there is a positive and significant influence between salesperson's behavior on salesperson's performance; 2) there is a positive and significant influence between planning sales activities on salesperson performance; 3 ) there is a positive and significant influence between performance orientation on salesperson performance; and 4) there is a positive and significant influence between salesperson behavior, sales activity planning, and performance orientation on salesperson performance.

Suggestions that can be given are that although the overall categorization for the salesperson's behavior variable is very good, there are still a small number of respondents on several indicators that show unfavorable conditions. In the indicator of knowledge about the company profile, there are still respondents who have poor knowledge. For indicators of product knowledge, respondents with poor abilities were also found, and in indicators of knowledge of company marketing strategies, respondents with poor abilities were also found. Salesforce as the front line and company representative in the field certainly reflects the company's image. If the above conditions are ignored, in addition to having an impact on sales performance, it will also result in a less credible employee image. Employee image will have an impact on company image. To overcome this, it can be done by conducting organizational development activities such as methods of sharing knowledge among employees through sales simulations and evaluations, brainstorming on sales strategies, daily briefings by supervisors, and training to institutionalize knowledge at the employee and company level.

\section{References}

Ames, Carole, and Archer, Jennifer (1988). Achievement Goals in the Classroom: Students' Learning Strategies and Motivation Processes. Journal of Educational Psychology, 80 (September), 260-67.

Anderson, Rolph (1995). Essentials of Personal Selling: The New Professionalism, Englewood Cliffs, NJ: Prentice-Hall.

Anderson, E., \& Oliver, R. L. (1987). Perspectives on behavior-based versus outcome-based salesforce control systems. Journal of Marketing, 51(4), 76-88.

Babakus, E., Cravens, D.W., Grant, K., Ingram, T.N., \& LaForge, R.W. (1996). Investigating the relationships among sales, management control, sales territory design, salesperson performance, and sales organization effectiveness. International Journal of Research in Marketing, 13(4), 345-363.

Barker, A. Tansu (1999). Benchmarks of Successful Salesforce Performance, Canadian Journal of Administrative Sciences, Vol.16, No.2. 
Baldauf, Arthur, David W. Cravens, and Nigel F. Piercy (200). Examining Business Strategy, Sales Management, and Salesperson Antecedent of Sales Organization Effectiveness, Journal of Personal Selling and Sales Management, Vol. XXI, No. 2, pp.109-122.

Behrman, Douglas N., and Perreault, William. (1982). Measuring the performance of industrial salespersons. Journal of Business Research, vol. 10, issue 3, 3553.

Boorom, Michael L., Jerry R. Goolsby, and Rosemary P. Ramsey (1998). Relational Communication Traits and Their Effect on Adaptiveness and Sales Performance, Journal of The Academy of Marketing Science, Vol. 26, No. 1, pp. 16-33.

Cravens, D.W., Thomas Ingram, Raymond W. LaForge, \& Clifford E. Yong (1993). Behavior-based and outcome-based salesforce control system. Journal of Marketing, 57 (October), 47-59.

Dalrymple, Douglas J. (1994). Sales Management: Concepts and Cases, ed. 5, NY: John Wiley.

Dweck, C. S., \& Leggett, E. L. (1988). A social-cognitive approach to motivation and personality. Psychological Review, 95, 256-273.

Dubinsky, Alan J., and Thomas E. Barry (1982). A Survey of Sales Management Practices. Industrial Management, Vol. 11 (April), p. 136.

Dweck, Carol S., and Leggett, Ellen L. (1988). A Social-Cognitive Approach to Motivation and Personality. Psychological Review, 95(2), 256-73.

Jackson, Donald W., Keith, Jackson Jr., and Schlacte, John L. (1983). Evaluation of Selling Performance: A Study of Current Practices. Journal of Personal Selling \& Sales Management, Volume 3, Issue 2, Pages: 42-51.

Kohli, Ajay K., Tasaddug A., Shervani, and Goutam N. Challagalla (1998). Learning and Performance Orientation of Salespeople: The Role of Supervisors.
Journal of Marketing Research, Vol. XXXV, pp. 263-274.

Kotler, Philip and Keller, Kevin Lane (2016). Marketing Management, 15th Edition, Pearson Education, Inc.

Kurniawati, Yulisa (2003). Analisis Analisis Pengaruh Perilaku Terhadap Kinerja Tenaga Penjual. Tesis Magister Manajemen. Universitas Diponegoro. Semarang. (Tidak Dipublikasikan).

Lilien, G. L., Rangaswamy, A., \& Matanovich, T. (1998). Harnessing expert judgment. Marketing Management, 7(3), 40.

Morris, Michael H., Davis, Duane L., Allen, Jeffrey W., and Avila, Ramon A. (2013). Assessing the Relationships Among Performance Measures, Managerial Practices, and Satisfaction When Evaluating the Salesforce: A Replication and Extension. Journal of Personal Selling and Sales Management, 11(3):2535.

Piercy, N.F., Cravems, D.W., \& Morgan, N.A. (1997). Sources of effectiveness in the business-to-business sales organization. Journal of Marketing Practice: Applied Marketing Science, 3 (1), 45-71.

Plank, Richard E., and Reid, David A. (1994). The Mediating Role of Sales Behavior: An Alternative Perspective of Sales Performance and Effectiveness. Journal Personal Selling and Sales Management, Vol. XIV, No. 3, pp. 43-56.

Rentz, Joseph O., C. David Shepherd, Armen Tashchian, Pratibha A. Dabholkar, and Robert T, Ladd (2002). A Measure of Selling Skill: Scale Development and Validation. Journal of Personal Selling and Sales Management, Vol. XXII, No. 1, pp. 13-21.

Sager, Ira (1994). The Few, the True, the Blue. Business Week, Mei 30, pp. 124126.

Sitompul, Denny Holan Hasiholan (2004). Pengaruh orientasi belajar dan komitmen organisasional terhadap kerja cerdas dalam meningkatkan kinerja penjualan. 
Jurnal Sains Pemasaran Indonesia, Vol 3, No 1 (2004): Mei.

Sujan, Harish, Barton A. Weitz, and Nirmalaya Kumar (1994). Learning Orientation Working Smart and Effective Selling. Journal of Marketing, Vol. 58, pp. 39-52.

Walker, 0. C. Jr., Churchill, G. A. Jr., Ford, N. M. (1977). Motivation and performance in industrial selling: present knowledge and needed research. Journal of Marketing Research, 14, 156-1 58.

Weitz, B. A. (1981). Effectiveness in sales interactions: A contingency framework. Journal of Marketing, 45(1), 85-103. 